\title{
我が国における出来高部分払方式の試行を通じた 効果・課題と改善策に関する考察
}

国土交通省国土技術政策総合研究所 溝口 宏樹* By Hiroki MIZOGUCHI

\begin{abstract}
「出来高部分払方式」は、短い間隔で出来高に応じた部分払や設計変更協議を実施する方 式であり、諸外国の公共工事では一般的に行われている。国土交通省では、平成13年 3 月か ら、2 件の工事で初めての試行を開始し、その後、平成15年度末までに116件（完成85件） の工事に試行を拡げ、フォローアップを行っているところである。

これらの試行を通じて、(1)より双務性の高い設計変更、(2)受発注者のコスト意識の向上、 (3)請負者・下請業者への工事代金の速やかな流通による経済効果の早期発現、(4)受注者の財 務状況の改善、(5)工事の品質の向上、(6)受発注者の技術力の向上等の効果が期待されること、 一方で、効率的な検查方法への改善等の課題があることを明らかにした。さらに、我が国の 公共工事における出来高部分払方式の今後の効果的・効率的な実施方法等について、その改 善策を示した。
\end{abstract}

【キーワード】出来高部分払、設計変更協議、建設契約

\section{1.はじめに}

我が国の公共工事の工事代金の支払や設計変更協 議に関する課題を踏まえ、国土交通省では、平成 13 年 3 月から 2 件の工事で、短い間隔で出来高に応じ た部分払や設計変更協議を行う「出来高部分払方式」 の初めての試行を開始した。この第一次試行工事の 約 1 年間にわたるモニタリング、諸外国の実態調査 等を通じて、効果の検証及び課題の抽出を行った。 これらにより、効果と課題がある程度明らかになっ たが、 2 件の工事のみで本方式の全ての評価を下す ことは適当ではなく、また、一層効果的かつ効率的 な実施に向けて、試行結果を次の実施方法にフィー ドバックしていくことが重要である。このため、平 成14年 8 月には、第一次試行等の結果を踏まえて統 一的な試行実施要領を定め、工事件数を大幅に増や し（平成15年度末までの発注工事116件)、試行を 全国に展開している。

本稿は、これまでの試行を通じて、出来高部分払 方式の実施による効果、実施上の課題について考察 するとともに、この方式を今後より効果的・効率的 に実施していくための改善策について述べるもので ある。

\section{2. 出来高部分払方式とは \\ (1) 導入の背景・目的}

諸外国の公共工事では、短い間隔で出来高に応じ て工事代金を支払う方式が一般的である。これに対 し、我が国の公共工事では、前払金（国の場合 $40 \%$ 以内）と完成払の 2 回の支払が通例となっている。

このような状況下で、工事代金の支払や設計変更 協議に関しては、(1)受発注者間で技術的に切硣环磨 する機会が少なく意思疎通が疎遠になりがちな問 題、(2)設計変更案件の精算を行う場合の片務性の問 題、(3)工事の進渉に応じたコスト管理意識の問題、 (4)元請下請間でのキャッシュフローの問題、などが 指摘されており、「支払の回数が少なく間隔が長い こと」や、「工期末にまとめて設計変更案件の精算 を行うこと」が、これらの一因となっているのでは ないかと推察される。

「出来高部分払方式(Progress Payment / プログレ ・ペイメト)」は、このような課題を踏まえ、短い間 隔で出来高に応じた部分払や設計変更協議を実施 し、円滑かつ速やかな工事代金の流通を確保するこ とによって、より双務性及び質の高い施工体制の確 保を目指すものである。 


\section{（2）出来高部分払方式の実施方法}

従来から一般的に行われている公共工事の支払方 式は、図ー1（上）のように、請負者は工事着手時 に請負金額の $40 \%$ を限度として前払金を請求し、工 事完成時に残りの $60 \%$ を受け取る。この場合、工事 の中間段階では、出来高に比べ、請負者の受け取る 工事代金が少ない時期が続く。また、請負者（元請） 等からその下請業者への支払は、現金と手形を併用 しているケースが約半数を占めているのが、我が国 の現状である。工事完成まで発注者から請負者へ出 来高に応じた工事代金が支払われない方式が一般的 になっていることは、下請業者への現金による支払 や、請負者・下請業者等への工事代金の流通といっ た効果が、十分発揮されにくい構造になっていると 言える。

一方、出来高部分払方式では、図－1（下）のよ うに、前払金と出来高に応じた部分払を行うことに より、工事代金の速やかな流通を確保し、受注者の 財務状況の改善、経済効果の早期発現を可能とする

（図ー2 )。また、併せて、従来は工期末にまとめ て設計変更案件の精算を行うことが多かったもの を、短い間隔で設計変更協議を実施し、その都度、 契約変更の対象であるか否かを双方で確認し、双務 性の向上等を図ることとしている。

具体的な実施方法については、2 件の第一次試行 工事の 1 年間のモニタリング、諸外国の実態調査の 結果等を踏まえて、可成14年 8 月に、統一的な試行 実施要領（図ー3 ) を定めた。現在、この実施要領 に基づき、工事件数を大幅に増やし全国各地で試行 を展開している。

\section{3 ．諸外国における支払方法等の実態}

出来高に応じて部分払を行っている欧州 3 力国 （ドイツ、オランダ、イギリス）9機関等の公共工 事に関して、公共工事契約の形態、工事代金支払方 法、検查、現場監理体制等の方法について、現地七 アリング (平成14年 1 月) 等による実態調査を行っ た（表一 1 )。我が国との相違に着目し、その結果 を以下に述べる。
従来の一般的な方式

\begin{tabular}{|c|}
\hline 前払金 着手 \\
\hline
\end{tabular}

出来高部分払方式

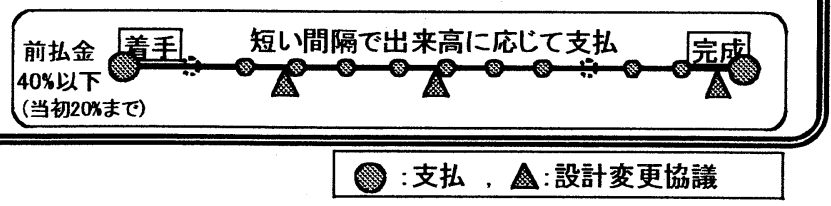

図-1 出来高部分払方式

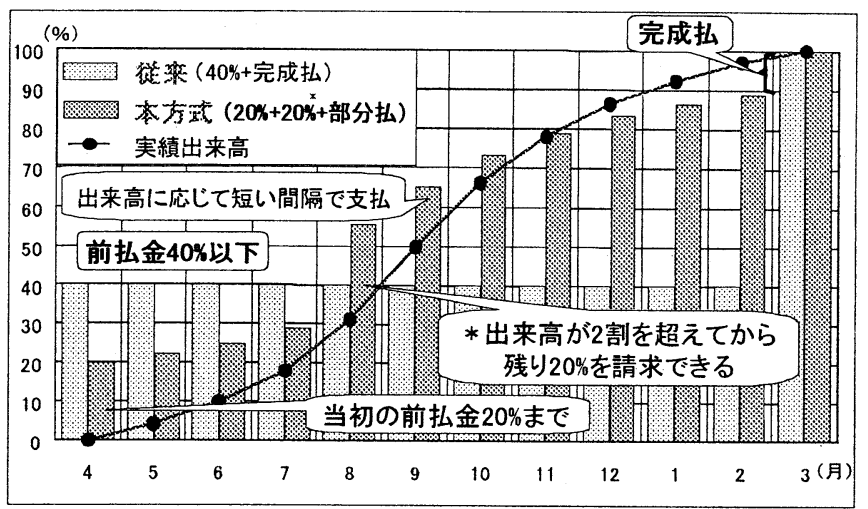

図-2 出来高と支払額の間係

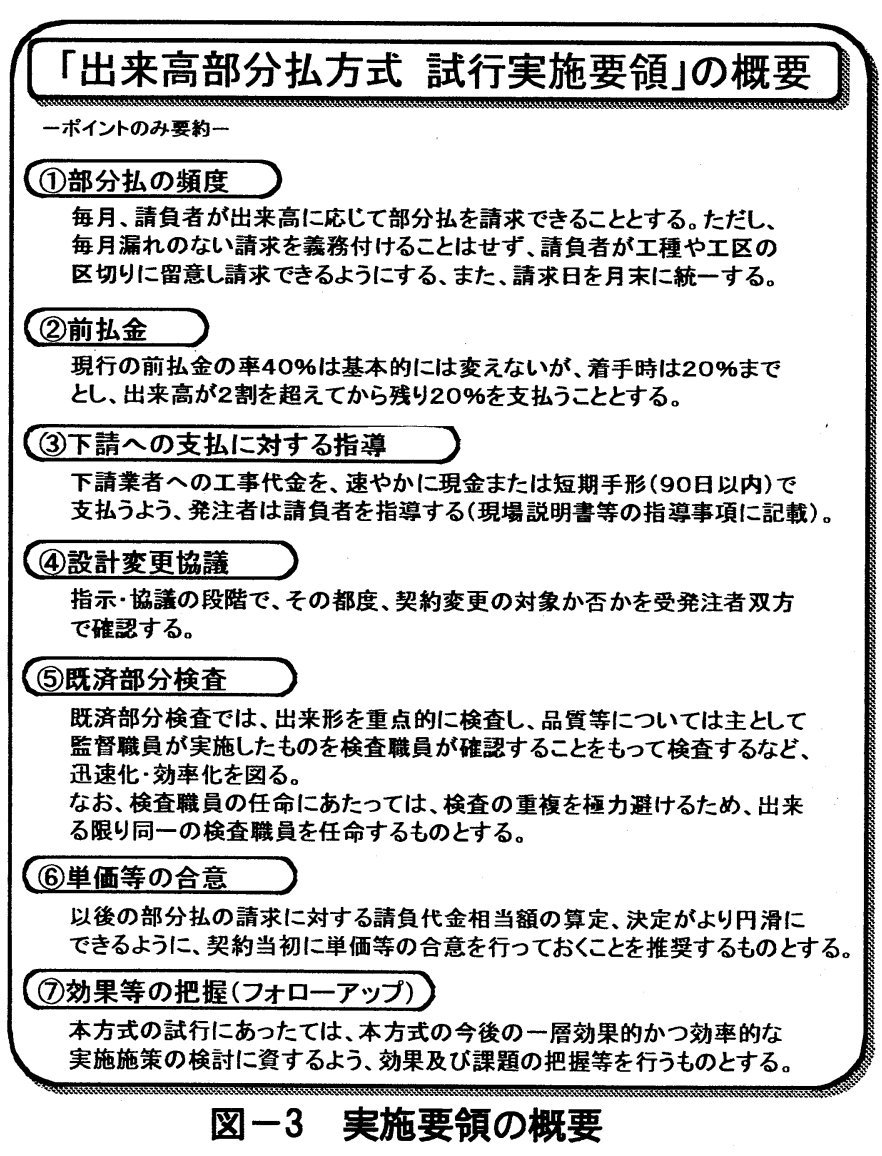




\section{表-1 調查対象の国・機闻等}

\begin{tabular}{|c|c|}
\hline 国名 & 訪問先機関名 \\
\hline \multirow{2}{*}{$\begin{array}{l}\text { ド } \\
\text { ツ } \\
\end{array}$} & $\begin{array}{l}\text { 連邦交通建設住宅省 建設都市計画局 } \\
\text { Federal Ministry of Transport.Building and Housing }\end{array}$ \\
\hline & $\begin{array}{l}\text { (社)ドイツ建設業中央連合会(HDB) } \\
\text { Hauptverband der Deutschen Bauindustrie e.V. }\end{array}$ \\
\hline \multirow{4}{*}{$\underset{\text { ダ }}{\stackrel{オ}{ラ}}$} & $\begin{array}{l}\text { 運輸水利省 公共事業水資源管理局 } \\
\text { Ministry of Transport Puulic Works and Water Management }\end{array}$ \\
\hline & $\begin{array}{l}\text { デルフトエ科大学 建設マネジメト研究室 } \\
\text { Delft University of Technology }\end{array}$ \\
\hline & $\begin{array}{l}\text { 運輸社会資本情報技術センター } \\
\text { Information Technology Center for Transport and Infrastructure(CROW) }\end{array}$ \\
\hline & $\begin{array}{l}\text { ハイマンス社 (建設会社) } \\
\text { Heimans Infrastructur en Milieu }\end{array}$ \\
\hline \multirow{3}{*}{$\begin{array}{l}1 \\
キ ゙ \\
\text { リ } \\
\text { ス }\end{array}$} & $\begin{array}{l}\text { 政府商務室(OGC) 資産·建設課 } \\
\text { Office of Government Gommerce }\end{array}$ \\
\hline & $\begin{array}{l}\text { 環境庁 } \\
\text { Environment Agency }\end{array}$ \\
\hline & $\begin{array}{l}\text { レデイング大学 建設マネジシン学部 } \\
\text { University of Reading }\end{array}$ \\
\hline
\end{tabular}

\section{（1）公共工事契約の形態}

ドイッ・オランダにおける公共工事契約は、一部 にデザインビルド契約方式もあるが、現時点では日 本と同様に、建設工事を単独で発注する契約形態が 主流となっている。一方、イギリスではPFI等の新 たな契約方式が主流を占め始めているが、ここでは、 伝統的な建設単独契約を中心に扱った。

ドイツ・オランダ・イギリス（建設単独契約）の 公共工事契約においては、各国ともに標準契約約款 が制定されており、いずれの契約方式でも工種毎の 単価契約が通常である(表一2)。

調査 3 力国では、工事単価が発注者と請負者で合 意されている点、および数量の増減が大きくなけれ ば契約変更なしに支払額が確定される点で、我が国 の契約方式（総価契約）と比ベスムーズに部分払を 実行できる契約方式となっている。

表一2 各国の主な契約・支払方法

\begin{tabular}{|c|c|c|c|c|}
\hline & 日 本 & ドイツ & オランダ & イギリス \\
\hline $\begin{array}{l}\text { 標準契約 } \\
\text { 約款名 }\end{array}$ & $\begin{array}{l}\text { 公共工事標準請 } \\
\text { 負契約約款 }\end{array}$ & $\begin{array}{l}\text { 標準工事 } \\
\text { 琶約約款 } \\
\text { (VOB B編) }\end{array}$ & $\begin{array}{c}\text { 標準行政規定 } \\
\text { (UAV) } \\
\text { 土木工事標準 } \\
\text { 士様(RAW) }\end{array}$ & ICE契約約款 \\
\hline $\begin{array}{l}\text { 主な契約 } \\
\text { 方法 }\end{array}$ & 総価契約 & 単価契約 & 単価契約 & $\begin{array}{c}\text { 単価契約 } \\
\text { (デザ 代似方 } \\
\text { 式は総価) }\end{array}$ \\
\hline $\begin{array}{c}\text { 主な支払 } \\
\text { 方法 }\end{array}$ & $\begin{array}{l}\text { 前払40\%(国) } \\
\text { 完成時60\% } \\
\\
\text { 上記に加元請負 } \\
\text { 者は. 部分払又 } \\
\text { は中間前払20\% } \\
\text { のいずれかを選 } \\
\text { 択して請求する } \\
\text { ことが可能 }\end{array}$ & $\begin{array}{l}\text { 2〜3週間ごとの } \\
\text { 出来高払 } \\
\text { (VOBには、できる } \\
\text { 限り短い期間」と規 } \\
\text { 定) } \\
\text { 前払金なし } \\
\text { (VOBに制度はある } \\
\text { が、あまり用いられ } \\
\text { ない) }\end{array}$ & 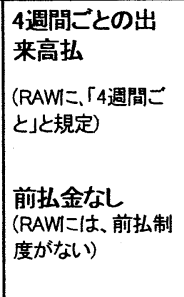 & $\begin{array}{l}\text { 毎月の出来 } \\
\text { 高厸 } \\
\text { (ICEI:「「毎月」と規 } \\
\text { 定) } \\
\text { 前払金なL } \\
\text { (ICEIは、前払制 } \\
\text { 度がないい) }\end{array}$ \\
\hline
\end{tabular}

（参考）日本道路公団：総価単価契約/3力月ごとの出来高·前払金 $40 \%$

\section{（2）工事代金の支払方法} (1)前払金・中間前払金

調査 3 力国では、公共工事において日本で支払わ れているような前払金、中間前払金が支払われるこ とはほとんどない。支払とは成果（行われた工事） に対する対価という考えが各国にあり、また、契約 時に請負者が履行保証として発注者へ資金を預託す る例もあり（ドイツ、オランダ）、日本とはかなり 状況が異なる。

\section{(2)部分払}

調査 3 力国ともに、工事の出来高に対して、2 週 間〜 1 ケ月間隔で部分払が実施されている。工事の 出来高以外にも、工場製品の現場搬入や材料の購入 に対しても部分払が行われることが多い。

オランダ、イギリスでは、支払間隔が標準約款等 で定められており、オランダではRAWにおいて 4 週 間毎、イギリスではICEにおいて1ヶ月毎と規定され ている。ドイッではVOBにおいて支払間隔を「出来 る限り短い期間区分で行われるものとする」と規定 されており、実際の支払は $2 \sim 3$ 週間毎に行われる ことが多い。

\section{(3)下請への支払}

調査 3 力国ともに、発注者から元請への支払と同 様に、元請から下請への支払も部分払が一般的であ り、現金で支払われている。

\section{（３）検查および現場監理体制}

部分払のための書類作成等の事務処理に対して、 各国の発注者および請負者ともに負担を感じるとの 意見は少数であった。

理由としては、作成書類が少ないことがまず挙げ られる。出来高を証明するための簡潔な数量計算書 が作成され、日報等の施工管理書類を用い出来高が 確認されている。一方、工事写真は、義務としてで はなく自主的に記録として撮られている。また、品 質管理は日常管理業務の一環として行われており、 部分払にあわせて書類検査を行うわけではない。

次に、現場管理の体制が挙げられる。部分払に関 する発注者、請負者あるいは第三者機関で、実質的 な支払の判断者について模式的に表わしたものが図 -4である。日本のように監督職員と検査職員を別 々に置いている例は調査 3 力国では見られない。 


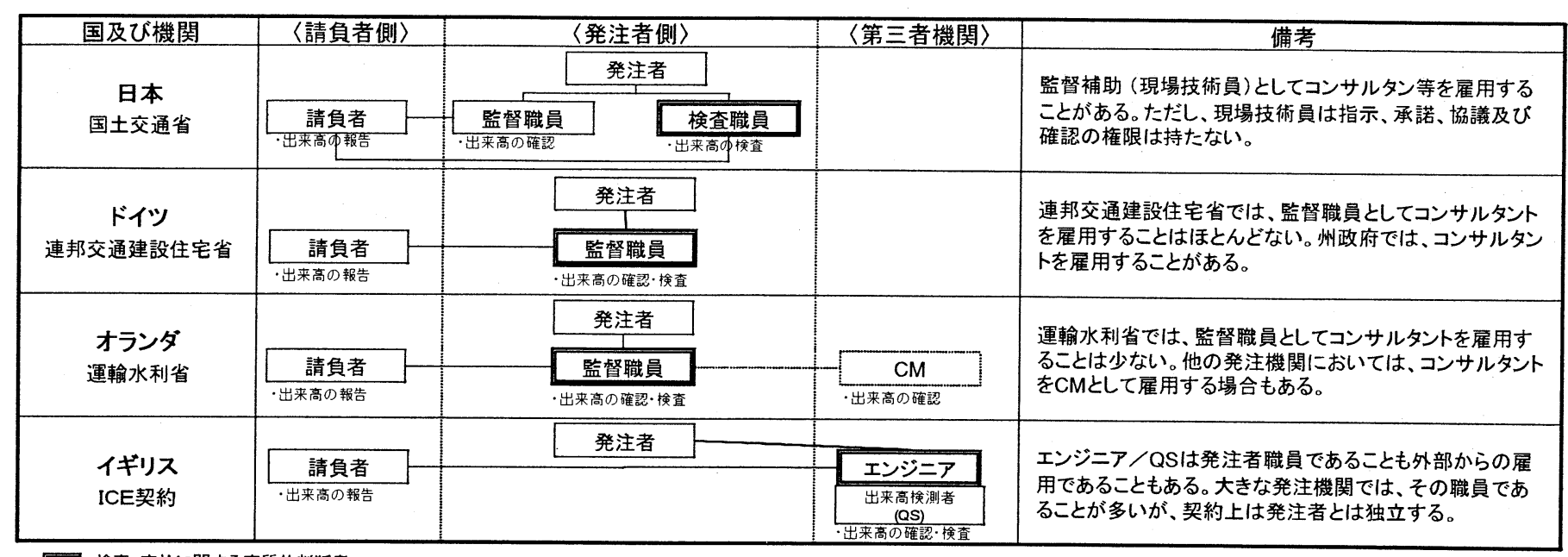

$\square$ : 検査·支払に関する実質的判断者

\section{図ー4 部分払に際しての出来高検查・支払に関しての役割}

日本では、発注者側の日常の工事監督は監督職員 により行われるが、支払検查は別の検査職員が実施 するよう予決令（第101条の7）で定められている。 一方、調查各国では検查職員を別に任命することは なく、監督職員の責任により部分払が行われている。 ただし、完成検查については、「本省から他の職員 が来て検査を行う(ドイツ連邦交通建設住宅省)」と のことで、部分払時とは異なった仕組みにより検査 が行われている。

\section{（4）設計変更·契約変更}

総価契約で実施される我が国の工事では、設計変 更には、仕様・工法等の変更といった主に単価に影 響を及ぼすために総額が変更になるものと、単価は 変わらないが工事数量が変わるために総額が変更と なるものの両方が含まれる。一方、調査各国の契約 は単価契約であるので、これら両者の違いをはっき り区別して理解する必要がある。

各国では、仕様・工法等の変更の場合、契約変更 が行われるまで支払は行われず、協議が長期間にわ たるケースもあるが、後者の単価変更がなく契約変 更を伴わない数量変更のみの設計変更の手続きは比 較的簡素となっている。

\section{（５）欧州 3 カ国から見た日本の支払方法}

前払時に $40 \%$ 、完成時に $60 \%$ の工事代金を支払う 我が国の方法について、調査 3 力国の 9 機関の面談 者に対し説明し、各面談者から得られた意見を表一
3 に示す。支払事務の効率化という観点から、日本 の方法はシンプルで良いとの意見も一部出たが、部 分払による各国の工事代金支払制度の方が合理的で あり長所が多いとの意見が大勢であった。

\section{表－3 各国から見た日本の支払方法 (前払金 $40 \%+$ 完成時60\%) \\ <3力国·9機関への聞き取りによる>}

\section{4.これまでの試行を通して得られた効果·課題 と改善策}

第一次試行工事（ 2 件）の約 1 年間にわたるモ二 タリング等を通じて、以下の効果が期待されること が明らかとなった（表一 4 )。

・日本の支払方法より、出来高に応じた部分払のほうが合理的と考える

(受発注者とも多数)

(少数)

その国の甲乙関係に関する文化·習慣も踏まえた上で、支払方法を

•モノもできていないのに、あらかじめ支払を行うことに違和感を感じる (多数)

•もし請負者が途中で倒産した場合などに困るのではないか

出来高に応じた部分払のほうが合理的と考える理由

・毎月出来高を確認し支払を行うことで、きちんと監督でき、品質にも

好影響

・完成時まで60\%支払われない方法と比較して、キャッシュフローが良い (多数)

既済部分検査に関する事務負担について

-検査に必要な書類や写真の作成-整理、事務処理の負担はほとんど 心いと思う受永注者とも部分払

-監督職員が日々出来高や品質を見ているのに、別の検査職員があら ためて検査する必要はないと感じる 
表-4 出来高部分払方式で期待される効果

\begin{tabular}{|c|c|c|}
\hline 期待される効果 & 主 な 効 果 & 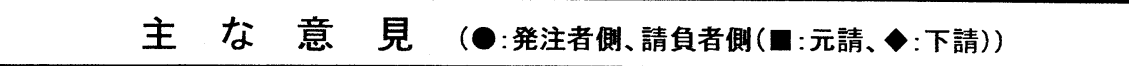 \\
\hline \multirow{3}{*}{$\begin{array}{l}\text { より双務性の } \\
\text { 高い設計変更 }\end{array}$} & $\begin{array}{l}\text { 設計変更に関する } \\
\text { リスクの回避 }\end{array}$ & ○思い込みや勘違いが少なくなりややリスク回避できた」 \\
\hline & タイムリーな協議 & 口「その都度協議を行うことにより最終段階での協議が少なくスムーズになったと感じる」 \\
\hline & $\begin{array}{l}\text { 受発注者間の } \\
\text { 意思疎通 }\end{array}$ & $\begin{array}{l}\text { 口「短い間隔で協議が行われることにより、現場代理人、監督員、積算担当者の3者間の } \\
\text { 意思踈通が図られた」 }\end{array}$ \\
\hline \multirow{3}{*}{$\begin{array}{l}\text { 受発注者の } \\
\text { コスト意識の向上 }\end{array}$} & $\begin{array}{l}\text { エ種毎の } \\
\text { コスト意識の向上 }\end{array}$ & ロ「エ種毎に出来高に応じたコストが確認できコスト意識が向上したと感じる」 \\
\hline & $\begin{array}{l}\text { コスト管理に対する } \\
\text { 意識の向上 }\end{array}$ & ロ「出来高と実コストとの差を把握することで、一層最終コストを意識するようになつた」 \\
\hline & $\begin{array}{l}\text { 時間管理に対する } \\
\text { 意識の向上 }\end{array}$ & の「施エの区切り毎に部分払を行うことで、エ事進渉の遅れに対する意識が高まった」 \\
\hline \multirow{3}{*}{ 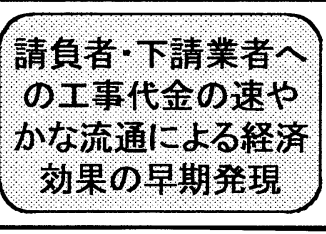 } & $\begin{array}{l}\text { 現金による } \\
\text { 支払の促進 }\end{array}$ & 口 『「下請への支払を現金払にした、手形の期間を短縮した」 \\
\hline & $\begin{array}{l}\text { 下請等への支払 } \\
\text { までの時間短縮 }\end{array}$ & 口「下請業者及び資材納入業者からの請求後に、以前より期間をおかずに支払ができた」 \\
\hline & $\begin{array}{l}\text { 機労材の } \\
\text { スムーズな調達 }\end{array}$ & •「部分払により労務、機械、資材の調達がスムーズになった」 \\
\hline \multirow{3}{*}{ 財務状況の改善 } & 借入金の削減 & 口 『借入金、支払利息が減少し、経営が安定した」 \\
\hline & $\begin{array}{l}\text { 資金計画が } \\
\text { 立てやすくなる }\end{array}$ & ロ「変更事項と支払金額が明らかになるので、不確定要素が減少し仕事をやりやすい」 \\
\hline & $\begin{array}{l}\text { 会社の } \\
\text { 信用不安の軽減 }\end{array}$ & $\begin{array}{l}\text { 『「元請から現金で受け取ることで安心でき、二次下請に現金で速やかに支払うことで信用不安 } \\
\text { がなくなる」 }\end{array}$ \\
\hline \multirow{2}{*}{$\begin{array}{l}\text { I事の } \\
\text { 品筫の向上 }\end{array}$} & 品質の向上 & $\begin{array}{l}\text { 口「既済部分検査時の指摘により、その後の施エにおいて是正されるため、最終的には、 } \\
\text { 品質及び出来ばえの向上か期待できる」 }\end{array}$ \\
\hline & $\begin{array}{l}\text { 品質確保のための } \\
\text { 意識向上 }\end{array}$ & 口「従来より多くの検査を段階的に行うことで、出来形·品質により一層の向上意識が働く」 \\
\hline \multirow{2}{*}{$\begin{array}{l}\text { 受発注者の } \\
\text { 技術カの向上 }\end{array}$} & $\begin{array}{l}\text { 切磋玩磨の機会増加 } \\
\text { による技術力の向上 } \\
\end{array}$ & $\begin{array}{l}\text { ○「数回の検査を受けることによって、検査官·発注者·受注者3者のディスかッションの場が増え、 } \\
\text { 相互の技術向上につながる」 }\end{array}$ \\
\hline & $\begin{array}{l}\text { 総合的な } \\
\text { 技術力の向上 }\end{array}$ & $\begin{array}{l}\text { ○出張所·現場·事務担当までエ事に携わるあらゆる人が、エ程やコストなど様々な総合的な } \\
\text { 技術に対して意識を持つようになっと思う」 }\end{array}$ \\
\hline
\end{tabular}

(1)より双務性の高い設計変更

(2)受発注者のコスト意識の向上

(3)請負者・下請業者への工事代金の速やかな流通

による経済効果の早期発現

(4)受注者の財務状況の改善

(5)工事の品質の向上

(6)受発注者の技術力の向上

一方で、効率的な検査方法への改善等の課題があ ることも明らかとなった。

この結果を踏まえ、さらに多くの試行を重ね、出 来高部分払方式の効果・課題をより明確にし、今後 の一層効果的 - 効率的な実施方法への改善策を検討 することが重要であるため、各試行工事において、 受発注者双方へのアンケートを中心としたフォロー アップを実施しているところである。

アンケートは、発注者側では、監督員、積算担当 者、検査官、経理担当者を対象者とし、受注者側で
は、元請（現場代理人、経理担当者、経営者）、下 請を対象者として行っている。

以下に、平成13～15年度発注の試行工事116件の うち、平成15年度末までに工期末を迎えた85件の工 事のフォローアップ結果から、試行を通じて得られ た効果・課題と改善策について考察する。

\section{(1) 試行工事の概要}

これまで完成した85件の試行工事の内訳を見る と、以下の特徵を有する。

【工期】

12 ケ月超が $14 \%$ (12件)、12ケ月以下が $86 \%$

(73件)で、工期12ヶ月以下の短いものが多い。

【契約金額】

3億円以上の工事が17\%(14件)、3億円未満

の工事が83\%(71件)で、大規模工事が少ない。

【部分払の実施回数】 
3回以上実施した工事が20\%(17件)、2回実施し た工事が35\%(30件)、1回実施した工事が45\% (38件)であり、部分払を3回以上実施した工事が 少ない。

このように、これまでのところ、工期の長い工事 や部分払回数の多い工事の割合が少ないため、結果 の評価の取扱いには、留意が必要と考えられる。平 成16年度も継続中の残りの31件の工事のうち18件 は、12ヶ月を超える工期の長い工事であり、今後は、 特に、工期の長い工事や部分払回数の多い工事にも 着目した分析・評価を行っていくことが必要であ る。

\section{（2）これまでの試行を通じて得られた効果に 関する考察 \\ (1より双務性の高い設計変更}

工期末にまとめて設計変更案件の協議・精算を行 う方法では、受発注者間での見込み違いによるトラ ブルが生ずる、その際の変更金額算定においては発 注者の積算単価が優先されがちで双務性の高い設計 変更となりにくい、などのケースがあるという指摘 がある。本方式の実施により、設計変更協議等を随 時その都度速やかに行うことにより、最終段階での 設計変更を巡る協議がスムーズにいかないといった リスクの回避などが期待される。

アンケートでは、発注者側 $19 \%$ 、請負者側 $25 \%$ が、 設計変更協議を随時実施することにより設計変更に 関するリスクを回避できるようになったと回答し、 発注者側に比べ請負者側に、見込み違いや片務性の 改善といったリスク回避の効果が多く見られる。こ のうち、協議等の回数が従来より増えた場合で見る と、 $42 \%$ の請負者側が設計変更に関するリスクが回 避できたとの回答をしており、設計変更案件が生じ た際にその都度協議することによる効果が現れてい ると考えられる(図一 5 )。

具体的な意見を見ると、「短い間隔で協議が行わ れることにより、現場代理人、監督員、積算担当者 の3者間の意思疎通が図られた」などの意見があり、 協議の過程において、受発注者間でのより一層の意 思疎通が図られ、双務性の高い設計変更を行いやす い環境が形成される状況がうかがえる。

今後、より効果を高めるためには、工期末にまと
めて設計変更案件の扱いを協議するのではなく、設 計変更の指示・協議の段階で、協議事項をその都度 確実に決着させることを徹底していくことが重要で ある。

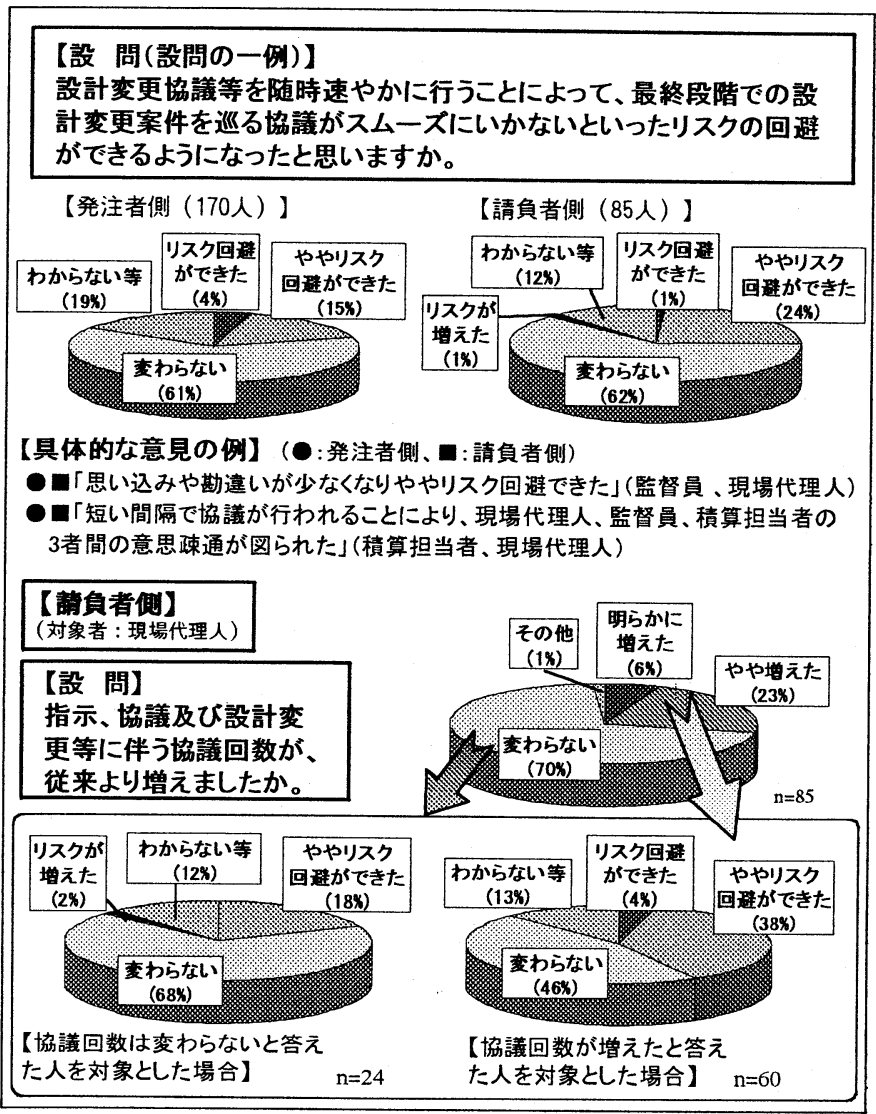

図ー5 より双務性の高い設計変更

\section{(2)受発注者のコスト意識の向上}

受発注者とも、コストについては従来から意識し ているという意見は多数あり、これは公共工事に携 わる者としてある面で当然であろう。ただし、特に、 工種毎のコストやコスト管理等の面を含めて見れ ば、従来に増して意識を高めていくことが必要であ る。工期末・完成時にまとめて設計変更案件の協議 ・精算、支払を行う方法に比べ、本方式では、短い 間隔で出来高に応じた部分払や設計変更協議を行う 過程において、工種毎の工事コストや工事の進渉状 況に応じた工事コストを把握することなどを通じ て、コストに関する幅広い観点からの受発注者の意 識の向上が期待される。

アンケートでは、発注者側 $27 \%$ 、請負者側 $51 \%$ \% 、 出来高に応じた部分払や設計変更協議を行う過程 で、工種毎などのコスト意識が向上すると回答して おり、発注者側より請負者側でその傾向が多く見ら 
れる(図一6)。

具体的な意見を見ると、「出来高と実コストの差 を把握することで、一層最終コストを意識するよう になった」などの意見があり、どういった条件のと き工種毎の単位面積・延長あたりの金額がどれぐら いかといったことのみならず、コスト管理に対する 意識の向上という効果も見られる。また、「施工の 区切り毎に部分払を行うことで、工事進渉の遅れに 対する意識が高まった」との意見もあり、時間管理 に対する意識の向上という観点での効果も確認され た。

今後、より効果を高めるためには、工事コストに 関して幅広く意識が高まるよう、短い間隔で出来高 に応じた部分払や設計変更協議を行うことを通じ て、コストについて把握・意識する機会を増やして いくことが重要である。

\begin{tabular}{|c|c|}
\hline \multicolumn{2}{|c|}{$\begin{array}{l}\text { 【設 問(設問の一例)】 } \\
\text { 本方式の央施により、コスト意識が向上する方向にあると感しままか。 }\end{array}$} \\
\hline 【発注者側（340人）】 & 【請負者側（170人）】 \\
\hline 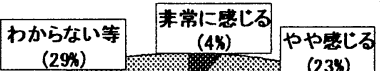 & 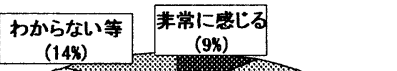 \\
\hline \multicolumn{2}{|c|}{ 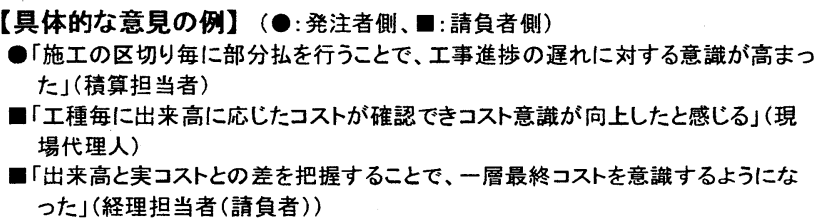 } \\
\hline
\end{tabular}

図-6 受発注者のコスト意識の向上

\section{(3)請負者・下請業者への工事代金の円滑かつ速やか な流通による経済効果の早期発現}

我が国の公共工事における下請代金支払・受取状 況の調査結果を見ると、現金と手形とを併用してい るケースが約半数を占めている現状にある。本方式 の実施により、発注者から請負者へ、短い問隔で出来 高に応じた部分払がなされることで、請負者等にと って、キャッシュフローが良くなり、その下請業者 に対し速やかな現金による工事代金の支払が行いや すい環境が形成される（図－7）。このように、工 事代金を短い間隔で部分払することで、請負者やあ らゆる下請業者へ工事代金が円滑かつ速やかに流通 することにより、経済効果の早期発現とともに、よ り質の高い施工体制の確保が期待される。
アンケートでは、下請への支払形態について、従 前から全額現金または短期手形で支払っている者を 除いた者を対象にすると、毎月現金で支払うように なった、手形の期間を短くした、現金の割合が高く なったなど下請への支払を改善したとの回答は、元 請34\%、下請16\%であった（図ー8）。

具体的な意見を見ると、「元請からの支払が早く なった分、二次下請会社への支払が早くなった」と の意見もあり、部分払をすることで、下請等への支 払までの時間短縮の効果も確認された。

ただし、ここで、実施要領には、「一次下請業者 に対する工事代金の支払いは速やかに現金又は90日 以内の手形で支払うよう指導する（現場説明書等の 指導事項に記載)」と規定されているものの、結果 として、従来「90日超の手形」で支払を行っていた 元請のうち、本方式の試行で「現金又は90日以下の 短期手形」とした元請は3割にとどまっていること に留意しなければならない。言い換えれば、7割は 依然90日超の手形で支払うなど、実施要領どおりに これまで試行されていないケースが多いことを意味 するものであり、本方式で期待される効果が必ずし も十分発揮されていないという大きな課題がある。

今後、より効果を高めるためには、受発注者間で、 本方式の主旨及び実施方法の一層の周知と、指導の 徹底を図り、発注者から部分払が行われた場合には 下請業者に対し速やかに現金等による支払が行われ るようにしていくことが必要である。

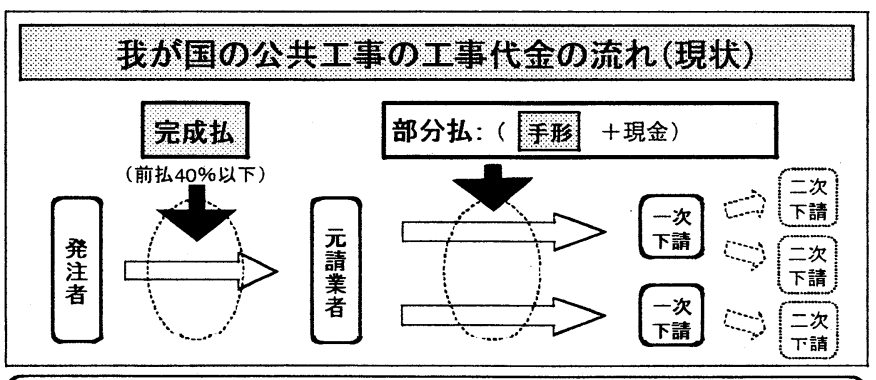

「出来高部分払方式によよる公共I事のI事代金の流れ

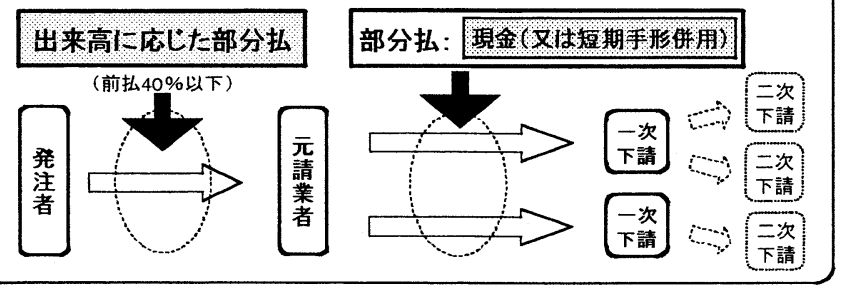

図-7 公共工事の工事代金の流れ 


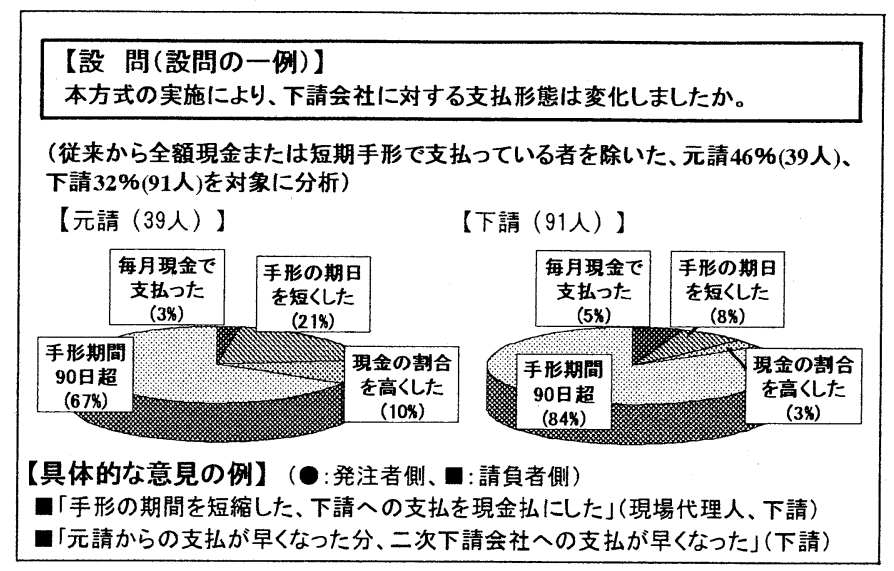

图-8 経済勏果の早期発現

\section{(4)受注者の財務状況の改善}

部分払や設計変更協議・契約変更の早期実施によ り、受注者にとって、工事実施に際しての借入金の 削減が可能になるとともに、契約上の不確定要素の 減少により現実的な資金計画が立てやすくなるなど 財務状況の改善が期待される。また、それに伴う下 請業者への支払状況の改善などが期待される。

アンケートでは、元請44\%、下請 $29 \%$ が本方式の実 施により、借入金の削減、資金計画が立てやすくな るなどの財務状況改善の効果があると感じている。 また、仮にほとんどの現場で短い間隔で支払が実施 されれば会社の経営は楽になると思うと元請 $60 \%$ 、 下請 $66 \%$ 回答しており、本方式が広く普及するこ とによる財務状況改善への期待感がうかがえる（図 -9 )。

具体的な意見を見ると、「工事代金の立替が少な くなり、資金運用が楽になると思う」「元請から現 金で受け取ることで安心でき、二次下請に現金で速やか に支払うことで信用不安がなくなる」との意見もあり、 部分払を行うことで、受注者の借入金の減少や、下 請への速やかな支払が可能となり、経営の安定や、 会社の信用が高まるなどの効果が期待される。

また、部分払による請負者の財務状況改善の効果 を見るため、東北地方整備局試行工事の出来高の実 績に基づき、借入金の状況等に着目したモデルによ り試算を行った（表一 5 ）。このモデルでの試算条 件は、請負者の当月の収入は前払金と前月の出来高 とし、支出は当月出来高分とした。収入が支出を上 回る場合は預金金利収入が生じ、下回る場合は借入 金利息負担が発生し、その金利収支の大小で評価し
ている。その結果、試算ケース(2)〜 (4)（前払金十部 分払）がほぼ同程度で金利収支が良く、前金ゼロの ケース(5)は当初の運転資金のために借入金の負担が 生じ、相対的にやや不利な結果となった。また、従 来方式のケース(1)（前払金十完成払）は、部分払の ケース(2)〜(5)に比べ、金利収支が悪い結果となって いることがわかる。

本試算では、収入と支出を単純に工事の出来高に 合わせて算出しており、実際の現場におけるキャッ シュフローとは異なるが、概ねの傾向は評価できる ものと思われる。なお、市中の金利の変動状況によ つて各ケースの試算結果は変わる場合もある。

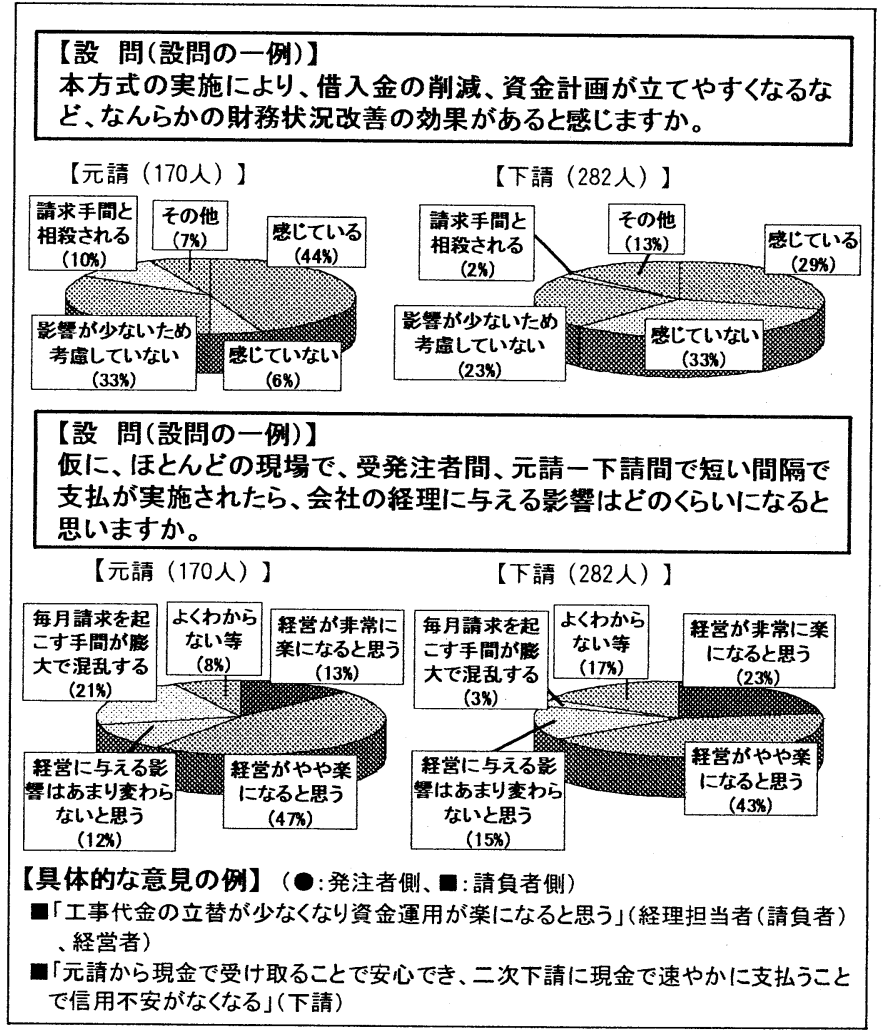

\section{図-9 受注者の財務状況の改善}

\section{表-5 金利収支試算結果}

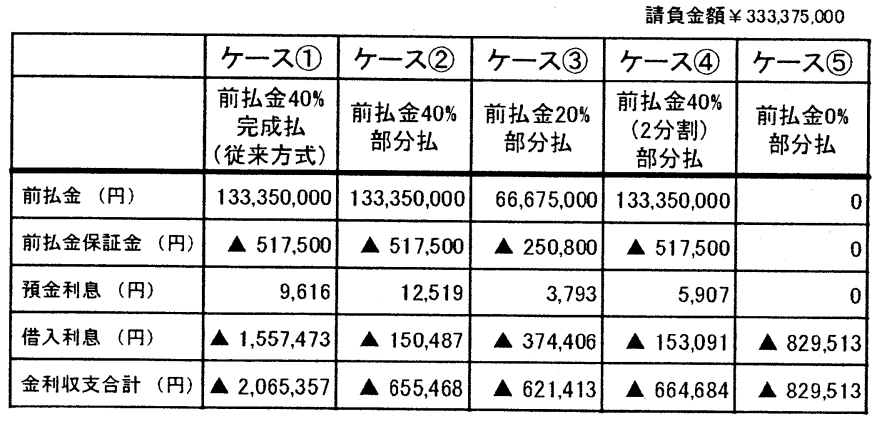

【試算条件】

(1)各月の出来高は、東北試行工事(二線堤山王江水門工事)の実績值を使用。(2)請負者は、毎月 当月出来高分の金額を当月に人件費、経費、材料費、下請代金として100\%支出するものと仮定。

(3)発注者から請負者への支払は、桯査等を経て翌月行うものとする。(4)前払金は、預金し利息が発 生。(5)前払金保証金は、「公共工事前払金保証の保証料」に基づき算出。6 (6) 預金金利は0.04\%/ 年、
借入金利は1.875\%/年と仮定。 


\section{(5)工事の品質の向上}

工期の途中、部分払を行うための既済部分検査を 行うことで、出来高の対象となる工種・工区につい てポイントを押さえた検査が行いやすくなるため、 その結果が以後の施工にも生かされ、工事の品質が 向上することが期待される。実際に部分払を実施し ている欧州各国への聞き取り結果を見ても、毎月出 来高を確認し支払うことで、より充実した監督・検 查ができ品質にも好影響があると捉えていることが わかる。

アンケートでは、発注者側 $54 \%$ 、請負者側 $57 \%$ 、 、 部分払を行う際の出来高確認、既済部分検查を実施 することによって、より目的物の品質、書類の程度 など工事の品質が向上する傾向にあると回答してお り、受発注者とも、半数以上が効果を感じている (図 $-10)$ 。

具体的な意見を見ると、「既済部分検査時の指摘 により、その後の施工において是正されるため、最 終的には品質及び出来ばえの向上が期待できる」と の意見が受発注者双方から出ているほか、「出来形 ・品質により一層の向上意識が働く」といった品質 確保のための意識向上の効果を指摘する意見も出て いる。

今後、より効果を高めるためには、工期途中での 既済部分検査の際に、重点的に検查を行うべき項目 を押さえ、ポイントを絞った効果的・効率的な検查 を実施していくことが重要である。

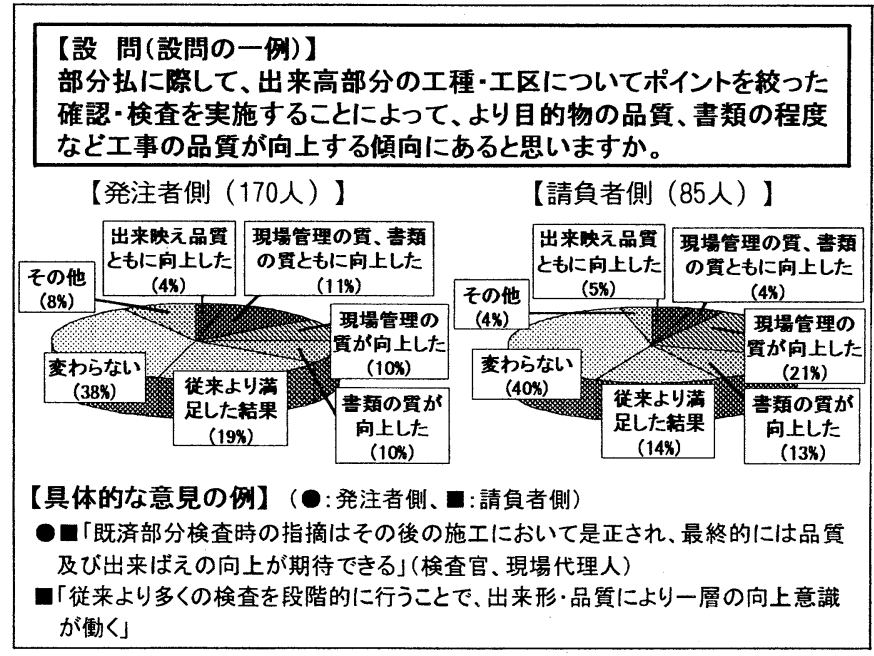

図-10 工事の品質の向上

\section{〔受発注者の技術力の向上}

随時行われる設計変更協議や既済部分検査の積み
重ねによって、発注者と受注者とが議論する場、互 いに切磋环磨する機会が増えることにより、受発注 者の技術力向上が期待される。

アンケートでは、発注者側 $32 \%$ 、請負者側 $45 \%$ が、 随時行われる設計変更協議や既済部分検查等を行う 過程において、技術的な向上があると回答している

(図-11)。

具体的な意見を見ると、「数回の検査を受けるこ とによって、検查官・発注者・受注者3者のディス カッションの場が増え、相互の技術向上につなが る」「土事に携わるあらゆる人が、工程やコスト など様々な総合的な技術に対して意識を持つように なった」などの意見があり、既済部分検查等の機会 を通じて、多様な技術の観点から、受発注者相互の 技術力が磨かれ向上する面があるという見方がなさ れている。

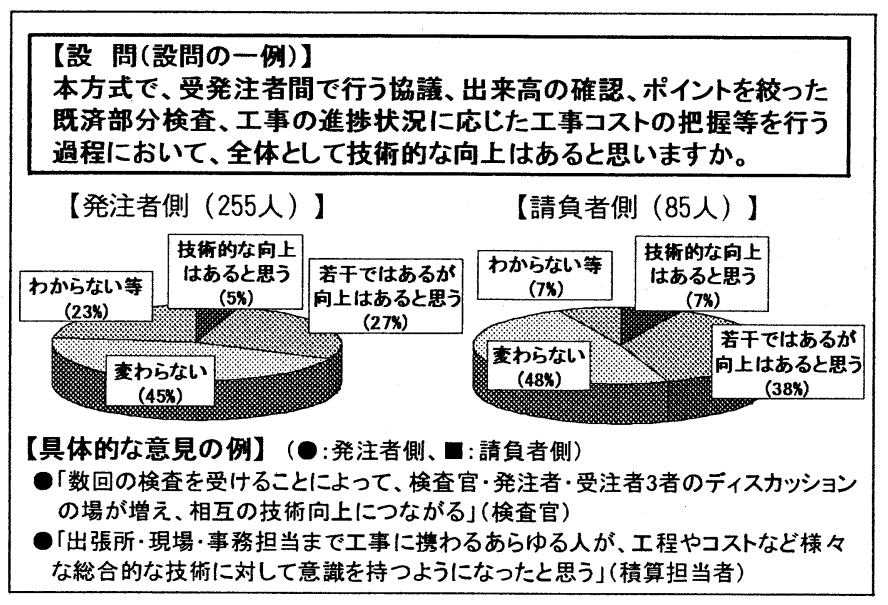

\section{図-11 受発注者の技術力の向上}

\section{（３）これまでの試行を通じて得られた課題と その改善策に開する考察}

効果の一方で、部分払に際しての請求（出来高報 告）・検査・支払事務などの本方式を効率的に実施 するための課題、下請への工事代金の速やかな流通 などの本方式のよる高い効果発揮のための課題など が挙げられる。

以下に、これまでの試行を通じて明らかになって きた課題と、本方式をより効率的かつ効果的に実施 するための改善策について、考察する。

\section{(1)睍済部分検查の方法·内容の効率化 （検查項目の絞り込み、新たな検查技術基準の策定）} アンケートでは、部分払回数に応じた検查回数の 
増加や受検準備作業の増加など、既済部分検査を実 施する段階での作業量が増加したという回答が、発 注者側 (検査官等) 54\%、請負者側 $59 \%$ であった（図 -12、13)。具体的な意見をみると、工種の途中段 階での出来高に関する資料作成に関する負担などが 挙げられている。

一方、作業量は変わらなかったという回答が、発 注者側 $31 \%$ 、受注者側 $38 \%$ あ゙あった。請負者側には、

「従来と比べて完成検査は楽であったため（トータ ルで見て）作業量増は０\%」という意見も複数あり、 作業が工期中で平準化され効率化が図られる側面が あるといえる。

これらの意見から見ても、従来の完成払方式と比 較すると、出来高部分払方式の場合、部分払の回数

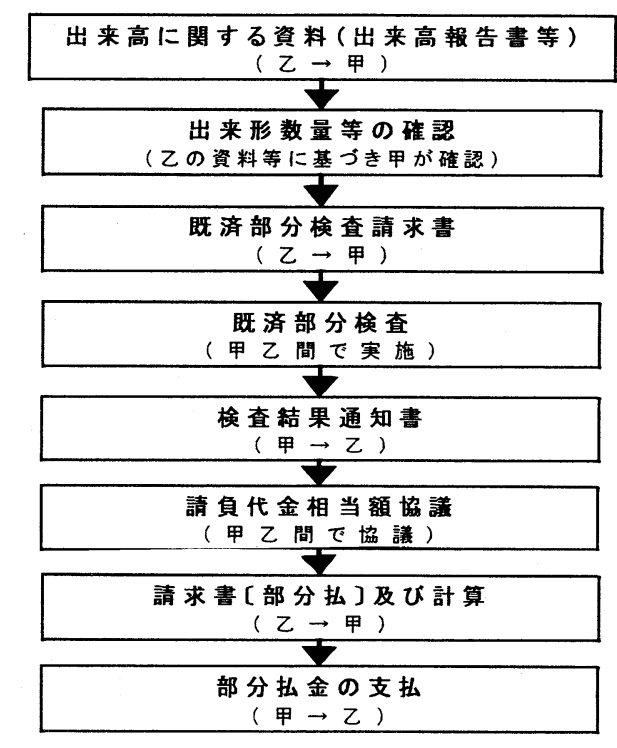

図ー12 部分払に関する概略フロー

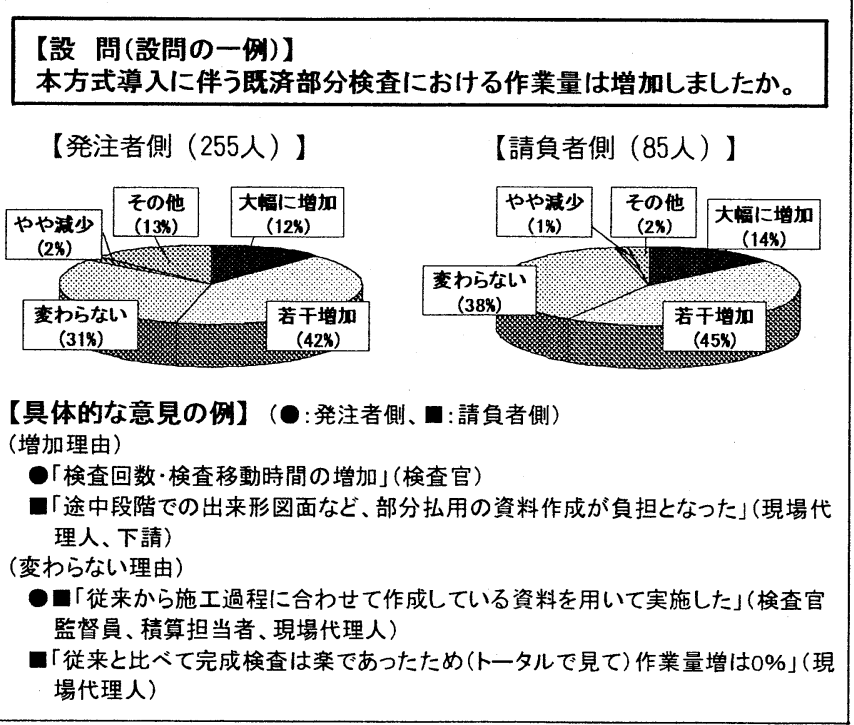

図-13 既済部分検查の作業量
に応じて既済部分検査という手順が加わるため、い かにしてこの既済部分検査を効率的に実施できるか が、本方式の定着を左右する大きな要素であると考 えられる。

既済部分検查を効率化する方法として、将来的に は、我が国においても諸外国と同様に、監督員が部 分払に際しての検査・支払の判断権限を持つことが できるよう、我が国の会計法令等の改正を行うこと もひとつの選択肢であると考えられる。その検討の 際には、監督と検査がそれぞれ果たすべき役割、発 注者と受注者の役割、公共工事の品質確保のあり方 などの観点から議論が必要であろう。

ここでは、現行の法制度の範囲内で、検査を効率 化する方法について述べる。

試行工事フォローアップの中では、検査に携わっ た検査官や請負者から、「既済部分検查専用の検查 技術基準がないため、完成検查を念頭に置いて定め られた土木工事検査技術基準（案）に基づいて検査 を行うことになり多大な時間を要してしまう小「検 査に向けて、必要以上の関連資料づくりをすること があり、請負者に負担がかかっている」「請負者 は検査官への印象を心配し、資料の体裁を重視して しまう」などの意見があった。このため、これらを 踏まえつつ検査の効率化策を検討し、新たに、出来 高部分払方式の既済部分検査を行うための専用の検 查技術基準として、具体的な検査の方法 - 内容を位 置付けた「既済部分検査技術基準（案）」を策定し た。この基準（案）は、中間技術検査及び完成検査 において出来形、品質等の適否の判断がなされるこ とを前提に、既済部分検查では、検查対象を出来高 と認めるのに必要な最低限の確認を行う、という考 え方に基づいており、特に、品質検查項目を工種毎 に絞り込み、効率化したことが大きな特徵である(図 $-14)$ 。

\section{【要点】}

・検査は実地を原則とするが、机上でもよい

- 複数回の既済部分検査で重複がないよう、検査済 部分は対象除外

・同一工種の 2 回目以降の検査の簡素化

- 出来高確認に必要な資料以外の検査準備の簡素化

（日常管理で作成する資料の有効活用）

- 出来高に直接関係しない工程管理等の項目の除外 
- 品質項目は、工種毎に、検査職員自ら重点的に検 査を行う項目を絞り込み など

既済部分検査技術基準（案）は、平成16年 3 月 30 日付で国土交通本省から関係部局に通達され、平成 16年 4 月 1 日から、出来高部分払方式適用工事の既 済部分検查において適用を開始した。今後、検查の 効率化が期待されるところである。

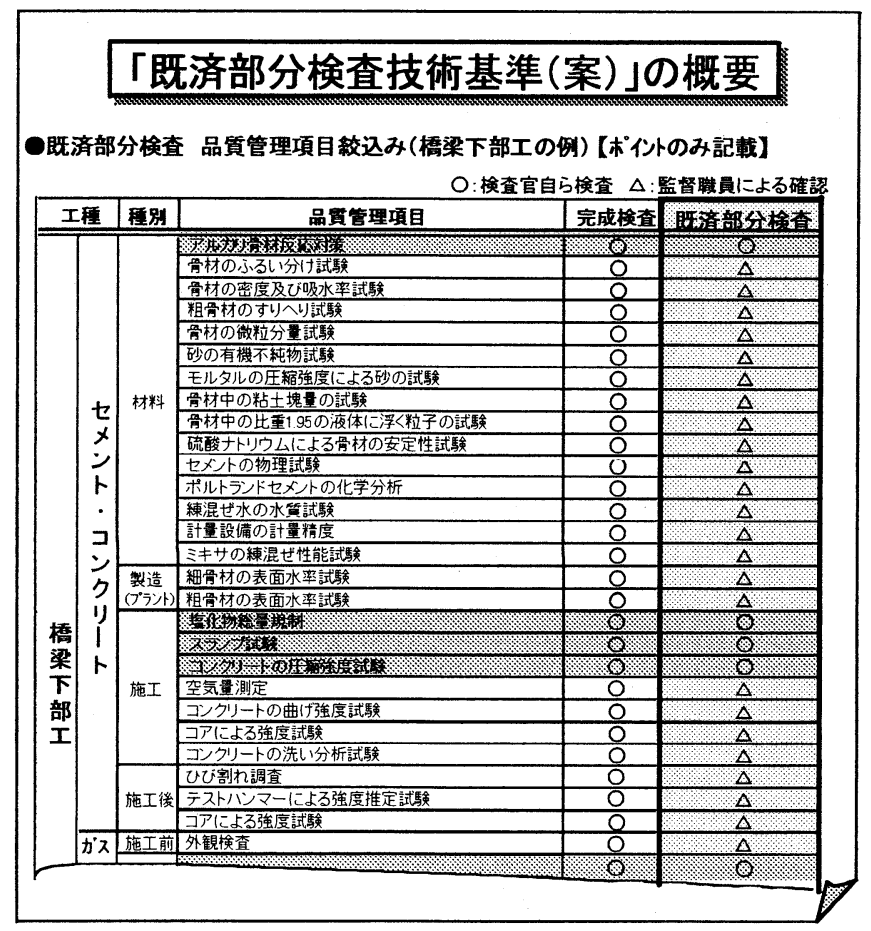

図一14 既済部分検查における 品質管理項目の絞り込み

(2)部分払の請求・検查を行いやすいタイミング確保 （工種等の区切りの良い時点での請求、マイルスト ーン方式の立案）

効率的な部分払の請求・検査等を可能にするに は、前項のような検査の方法・内容自体を効率化す る視点のほか、工種等の区切りの良い時点を捉える どにより請求・検查を行いやすくする視点から、効 率化の方策を検討することも必要である。

アンケートでは、部分払の頻度（時期）は工種・ 工区の区切りがよいとする意見が、発注者側 $52 \%$ 、 請負者側 $49 \%$ と最も多かった。現行の実施要領では、 「請負者が毎月出来高に応じて請求可能小「請負 者が工種や工区の区切りなどにも留意しながら請求 できるものであり、毎月もれなくまた出来高部分の 全てを請求することを義務付けるものではない」と している。今回のアンケートで適切とする意見が多 かった工種・工区の区切りでの請求、毎月の請求な
ど、いずれを選択することも請負者にとって可能で あり、この点では、各種の要請に対応できる仕組み になっていると考えられる。

しかしながら、前述のとおり、部分払回数が 3 回 以上の工事はこれまで20\%にとどまっている。前項 で述べた検査方法自体の課題のほかに、受発注者と も、どのタイミングで部分払の請求を行えば効率的 かという感覚が十分つかめていないことも、その一 因と見られる。例えば、施工計画書の提出時など早 い段階で、甲乙間であらかじめ、工種や工区の区切 りの良い時点を確認し、部分払のタイミングについ て意見交換しておくことが有効である。

さらには、予め支払対象とする出来高を設定（目 標值）しておき、その出来高を超えたと判断した段 階で目標值分の出来高を支払う「マイルストーン方 式」の採用など、出来高の確認・算定が容易な方法 を立案・採用していくことも有効な改善策であると 考えられる。

\section{(3)部分払の金額算定 · 決定方法の明確化 （単価合意の浸透、出来高の取扱の明確化）}

部分払の金額の算定・決定がより円滑にできるよ う、契約当初に単価合意を実施することを推奨した が、これまでに実施した工事は、85件中8件（9\%） にとどまっている。

しかしながら、アンケートでは、発注者側 $58 \%$ 、 請負者側 $98 \%$ が単価合意を行ったほうがよいと回答 している（図一15）。特に、請負者側では、ほぼ全 てが単価合意を行ったほうがよいと回答しており、 部分払の単価や、後に設計変更が生じた際の変更金 額の算定が明確になることに対する期待感が現れて いると考えられる。

我が国の公共工事では、道路関係公団以外ではこ れまで単価合意を実施してきていないため、国土交 通省では、平成13〜15年度の間に 36 件の工事で、総 価契約単価合意方式の試行を行っている。加えて、 平成16年度下半期から試行を開始することとしてい るユニットプライス型積算方式においても、総価契 約の後に単価合意のステップが組み込まれる。これ らの試行を行う中で、合意の方法・手順等の確立・ 浸透を図っていくことが必要である。

また、仮設工など一式計上の工種、品質確認まで 
時間がかかる工種、数量増減や単価増減があった工 種等について、出来高として認める対象・取扱につ いて判断しづらいところがあるため、出来高の取扱 方法を要領化し、判断が円滑にできるように改善し ていくことが必要である。

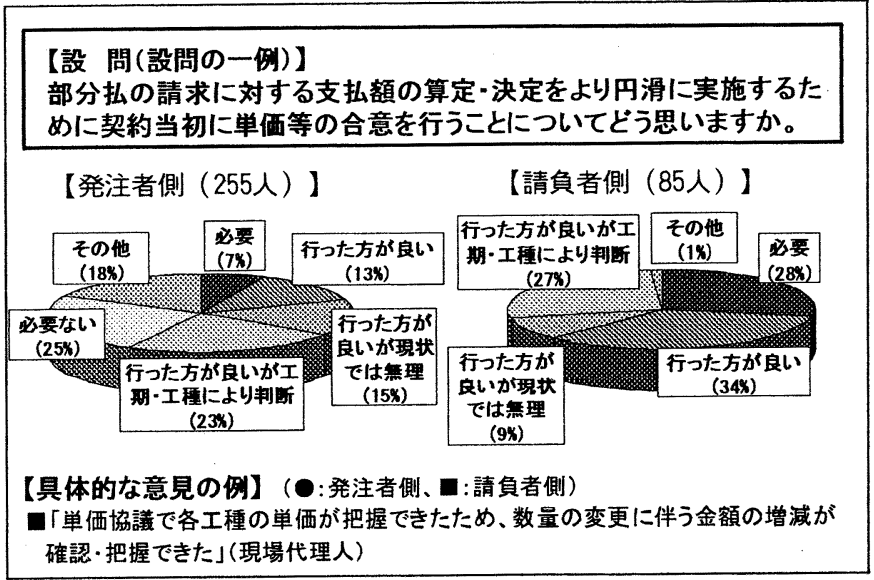

\section{図-15 単価合意}

\section{(4)下請業者への現金等による支払の浸透}

「(2 ) (3)」において述べたとおり、毎月現金で 支払うようになった、手形の期間を短くした、現金 の割合が高くなったなど、下請への支払を改善した との回答は、これまで元請34\%、下請16\%にとどま っている(図-8)。

実施要領には、「一次下請業者に対する工事代金 の支払いは速やかに現金又は90日以内の手形で支払 うよう指導する（現場説明書等の指導事項に記載）」 と規定されているものの、実施要領どおり試行され ていないケースが多い。このため、本方式の主要な 目的のひとつである「あらゆる下請を含めた工事代 金の速やかな流通」という効果が、必ずしも十分発 揮されていないという課題がある。

具体的な意見を見ると、「多くの工事で部分払さ れないと（自社の）支払規定を変更できない」とい った理由や、「効果を上げるには、本方式を十分理 解し、元請・下請共に全社挙げて取り組むことが必 要」との意見があり、受発注者双方への本方式の主 旨の一層の周知、指導の徹底を行い、浸透を図って いく必要がある。

\section{(5)合理的な前払金の設定}

アンケートでは、請負代金額の $40 \%$ 程度の前払金 が必要だとする請負者側の意見が44\%、30\%程度以
下を選択した意見が43\%であった（図ー16）。

特に工事の初期段階では出来高に現れにくい準備 工等に関する費用を要することや、我が国の商慣習 を勘案すると、出来高部分払方式の実施においても 前払金が支払われることが合理的であると考えられ る。現在、従来からの前払金の率 $40 \%$ は基本的には 変えず、着手時は $20 \%$ までとし、出来高が 2 割を超 えてから残り $20 \%$ 支払うこととしており、アンケ 一ト結果から見れば現在の試行方法は概ね当を得て いると言えよう。

今後も引き続き試行状況を調査した上で、合理的 な前仏金の設定について検証していく予定である。

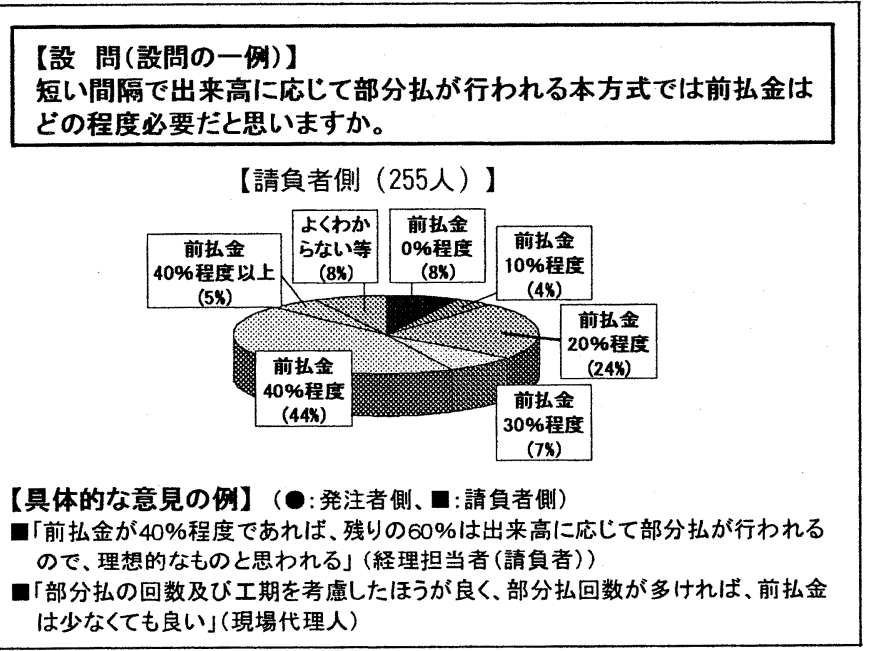

\section{図-16 前払金}

\section{(6)試行結果のフォローアップとより良い実施方法へ の改善}

これまで第一次試行工事 2 件と、このモニタリン グ等から得た知見により定めた実施要領に基づき試 行を行った85件の工事のフォローアップを通じて、 効果・課題と、課題に対する改善策が明らかになっ てきた。それを、今後の実施にフィードバックする 仕組みにより、さらに効果的・効率的な方法を見出 し、より良い実施方法の確立を図っていくことが重 要である(図ー17)。

\section{5. おわりに}

ここまで述べたように、まだ、必ずしも出来高部 分払方式の主旨や実施方法が、現場で十分理解され てない面がある。このため、今後さらに、受発注者 双方に出来高部分払方式の主旨・実施方法を周知し 浸透を図っていくことが重要である。 
また、これまでのところ、工期の長い工事や部分 払回数の多い工事の割合が少ないため、特に、工 期の長い工事や部分払回数の多い工事にも着目し、 フォローアップを重ねていく必要がある。

今後、さらに現場での試行を通じて効果や課題を 明確にし、その改善を通じてより効果的・効率的な 方法の確立を目指すと同時に、多くの試行の結果を もとにして、我が国の公共工事への出来高部分払方 式の本格導入について、各方面からの活発な議論を 期待したい。

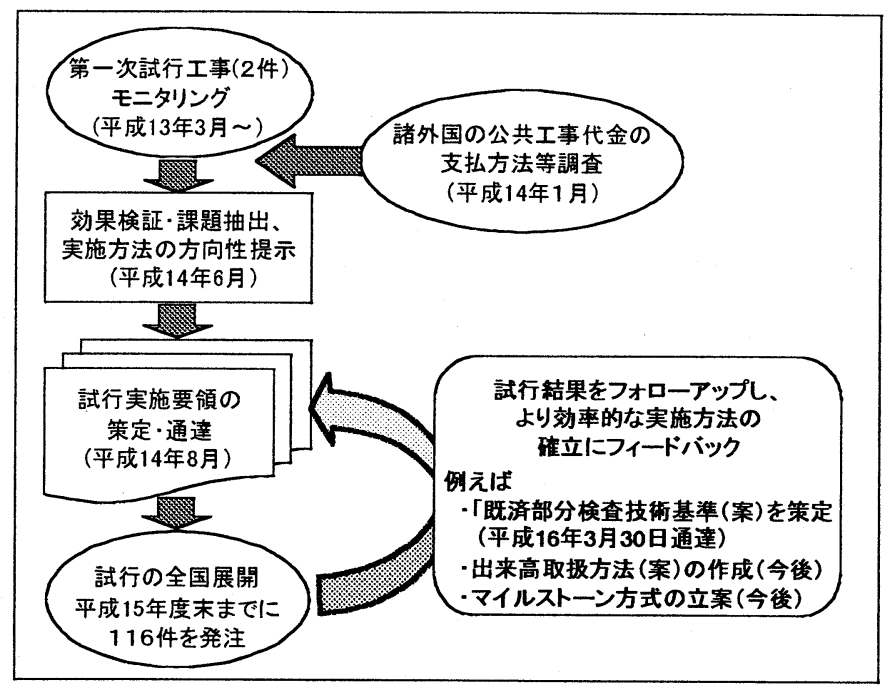

図-17 出来高部分払方式の試行 · 改善フロー

\title{
【参考文献】
}

1)定期一設計変更協議·部分払方式実施研究会 : 出来 高部分払方式検討報告書、2002

2)国土交通省国土技術政策総合研究所：欧州（ドイ ツ・オランダ・イギリス）における公共工事代金

の支払方法等に関する調査報告書、2002

3)国土交通省総合政策局建設業課 : 平成15年度下請 代金支払状況等実態調查・下請代金受取状況等実 態調查、2003

\section{Consideration of Progress Payment for Public Construction Works in JAPAN through Trial Application to Projects}

\author{
By Hiroki MIZOGUCHI
}

In 2001, a progress payment system for public works was adopted for two projects as a trial basis in Japan and its effectiveness compared with the traditional system were examined and verified. Furthermore, in 2002, a standard implementation program for the new payment system was produced by the Ministry of Land, Infrastructure and Transportation, and therefore many trial projects for the new payment system were commenced all over Japan. In this report, we present the results of the consideration of the effectiveness, practical problems and improvement plans of adopting new payment system, based on the follow-up questionnaire survey for trial projects. 